\title{
EFEKTIFITAS PENGGUNAAN PEWARNA ALTERNATIF PREPARAT PERMANEN TELUR NEMATODA KOLON MENGGUNAKAN PEWARNA RHODAMIN B
}

\author{
Saadah Siregar ${ }^{1}$, Visensius Krisdianilo² ${ }^{2}$ Vincentia Ade Rizky ${ }^{3}$ \\ Institut Kesehatan Medistra Lubuk Pakam \\ Jalan Sudirman No.38 Kabupaten Deliserdang Sumatra Utara \\ Email: Saadahsiregar20@gmail.com \\ DOI : https://doi.org/10.35451/jfm.v2i1.194
}

\begin{abstract}
Staining is one of support microscopic examination in the identification of worm eggs. Staining techniques are needed to clarify the various elements and the description of the microscopic worm eggs and distinguish it from the surrounding dirt. Hematoxylin and Eosin staining method that is widely used in the staining of histological tissue. Dyes commonly used in the examination of intestinal nematode eggs on is dye eosin. To added reference dye Rhodamine $B$ dye used as an alternative to dye eosin. The method used is experiment by conducting concentration ratio of Rhodamine B 1\%, 1.5\%, 2\% and $2.5 \%$ to $2 \%$ eosin control. The results based on Kruskal-Wallis Test showed the normality test is $0.357, p$-value sig $(0.357)>0.05$, so that the data group to be tested otherwise normal. Then performed statistical tests KruskalWallisTtest to determine the accuracy of the file thus obtained p-value $(0.407)>0.05$, meaning there is no significant difference in the variasion of the dye Rhodamine $B$ of the entire treatment. Morphology of worm eggs clearly visible from the outside layer to the inside layer, the visual field Rhodamine $B$ dye is clearly visible, color contrast eggs are also clearly visible. From the research conducted, it can be concluded that the dye Rhodamine $B$ dye can be used as an alternative to dye eosin.
\end{abstract}

Keywords : Intestinal Nematode Eggs, Hematoxylin - Eosin, Rhodamine B 


\section{PENDAHULUAN}

Infeksi oleh cacing dapat disebabkan oleh beberapa faktor, seperti sanitasi lingkungan dan higienitas setiap orang yang kurang baik, mengkonsumsi makanan yang diduga terkontaminasi oleh telur cacing karena kurangnya kebersihan dan pengolahan makanan, tingkat pengetahuan dan tingkat ekonomi yang masih rendah. Sedangkan penularannya dapat melalui beberapa cara yaitu dibawah oleh perantara vektor, larva yang dapat bagian kulit dan mengkonsumsi jenis telur cacing yang infektif dengan cara melalui jari- jari tangan yang tidak bersih sehingga diakibatkan terdapat beberapa telur cacing sehingga menkontaminasi human. khkolonnya telur Nematoda kolon seperti Ascaris lumbricoides, Trichuris trichiura dan Ancylostoma $s p$ dan Necator americanus (cacing tambang) (Onggowaluyo, 2002).

Parasit merupakan suatu organisme berukuran kecil, sehingga untuk mengidentifikasi serta melihat ciri khas dengan jelas diperlukan pemeriksaan mikroskopis. Golongan cacing kolon (Nematoda Kolon) untuk perkembang biakan telurnya menjadi infektif membutuhkan tanah. Parasit yang termasuk golongan Soil Transmitted Helminths yang berdiam Pada bagian kolon manusia adalah Ascaris lumbricoides, Hookworm (Necator amerikanus dan Ancylostoma duodenale), Strongiloides stercoralis, Trichuris trichiura. Sedangkan yang habitatnya pada Kolon hewan adalah Toxocara canis, Toxocara Cati, Ancylostoma braziliense, Ancylostoma ceylanicum, Ancylostoma caninum (Widiyono, 2005).

Preparat Awetan adalah tindakan atau proses pembuatan maupun penyiapan sesuatu menjadi tersedia, sampel patologi maupun anatomi yang siap dan diawetkan untuk penelitian dan pemeriksaan (W.A. New Dorland, 2002). Pada umumnya metode pembuatan sediaan preparat permanen telur cacing jarang sekali dilakukan dalam proses pembelajaran dan ketersediaan preparat permanen yang terbatas. Selain itu, pewarnaan permanen digunakan untuk media pembelajaran. Dalam bidang medis, adanya sediaan preparat permanen diharapkan membantu menegakkan diagnosa dokter tentang penyakit yang disebabkan oleh parasit. Sediaan permanen dapat memberikan suatu penjelasan yang ringkas dengan ilustrasi yang baik tentang fakta-fakta dasar dan interpretasi hasil dari anatomi mikroskopis yang dapat dilihat (Junquiera dkk, 1998). Salah satu penunjang pemeriksaan mikroskopis adalah dengan pewarnaan. Teknik pewarnaan sangat diperlukan untuk memperjelas berbagai unsur serta gambaran mikroskopis telur cacing dan membedakannya dengan kotoran disekitarnya (Pradi, 2011).

Hematoksilin dan Eosin adalah metode pewarnaan yang banyak digunakan dalam dalam pewarnaan jaringan histologi, sehingga diperlukan dalam diagnosa medis dan penelitian. Hematoksilin adalah bahan pewarna yang sering digunakan pada pewarnaan histoteknik, ia merupakan ekstrak dari pohon yang diberi nama logwood tree.

Hematoksilin bekerja sebagai pewarna basa, artinya zat ini mewarnai unsur basofilik jaringan. Tujuan pewarnaan adalah untuk meningkatkan kontras alami dan untuk lebih memperjelas berbagai unsur, dan gambaran mikroskopis telur cacing (LEESON, C.Roland,2009). 
Received: 05 September 2019 :: Accepted: 14 September 2019 :: Published: 31 Oktober 2019

Rhodamin B adalah salah satu zat pewarna sintetis yang biasa digunakan pada industri tekstil dan kertas. Rhodamin B merupakan zat golongan xanthenes. Rumus molekul dari rhodamin $B$ adalah $\mathrm{C}_{28} \mathrm{H}_{31} \mathrm{~N}_{2} \mathrm{O}_{3} \mathrm{Cl}$ dengan berat molekul sebesar 479.000. Rhodamin B adalah pewarna sintetis yang berasal dari metanlinilat dan dipanel alanin yang berbentuk serbuk kristal berwarna kehijauan, berwarna merah kegunaan

\section{METODE PENELITIAN}

Penelitian ini bersifat eksperimen dengan desain penelitian yang digunakan adalah perbandingan kelompok statis (static group comparasion) yaitu membandingkan pemeriksaan pewarnaan telur cacing yang dilakukan dengan membandingkan kelompok eksperimen dengan kontrol (Notoatmojo, 2002; Barus B, 2018).

Sampel yang digunakan adalah feses yang positif terinfeksi cacing Nemtodakolon. Penelitian dilakukan di Laboratorium Institut Kesehatan Medistra Lubuk Pakam.

\section{Alat dan Bahan}

Alat yang digunakan adalah Mikroskop, Kaca objek, kaca penutup, pipet tetes, pot plastik, ose, botol kaca, tissue handskun dan stopwatch label.

Bahan yang digunakan adalah Larutan Hematoxylin, Eosin, Rhodamin B, Alkohol Absolut, Iodine Alkohol, Alkohol 50\%, Alkohol 60\%, Alkohol 70\%, Alkohol 80\%, Alkohol 95\%, Xylol, Aquades, Entelan, Ferri Amonium, Sulfat 2\%, Asam pikrat jenuh, Formalin 10\%, Suspensi Feses.

\section{Cara Kerja}

\section{Pembuatan Suspensi Feses}

Feses ditambah formalin $10 \%$, diaduk sampai homogeny, Ditambah aquades, diaduk dan disaring kembali, Hasil saringan di sentrifugasi selama 5 menit dalam bentuk terlarut pada konsentrasi tinggi dan berwarna merah pada konsentrasi rendah (Parhan,2018).

Peneliti telah melakukan penelitian dengan menggunakan rhodamin $B$ denagan konsentrasi $1 \%, 1,5 \%, 2 \%$ dan $2,5 \%$ bisa mewarnai telur cacing. Dari hasil penelitian, pewarna rhodamin B menghasilkan warna yang lebih kontras dibanding dengan pewarna eosin.

dengan kecepatan 2500 rpm, Supenatan dibuang dan ditambah aquades lagi sama banyak kedalam filtrat yang berisi feses, Suspensi dapat digunakan sebagai sampel

\section{Pemeriksaan Telur Cacing dengan Pewarnaan Hematoksilin - Eosin}

Disiapkan semua alat dan bahan untuk pembuatan sediaan apusan tinja. Diaduk bahan suspensi telur cacing sampai homogen. Diambil dengan pipet 2-3 tetes larutan suspensi, apuskan pada kaca benda di bagian tengah sampai hampir menutupi seluruh permukaan kaca benda dikeringkan sediaan selama beberapa jam. Sediaan apusdifiksasi dengan larutan alkohol $70 \%$ selama paling sedikit 15 menit. Dicelupkan sediaan 2-5 menit berturut-turut dalam larutan alkohol $70 \%$, larutan alkohol $60 \%$, larutan alkohol 50\%. Dicuci dengan air mengalir 2-3 menit. Dimasukan sediaan kedalam larutan ferik-amonium sulfat $2 \%$ selama 5-15 menit. Dicuci dengan air mengalir 35 menit. Dimasukkan sediaan kedalam larutan hematoksilin 5-15 menit. Dicuci dengan air mengalir 2-3 menit. Diferensiasi dilakukan dengan mencelup sediian dalam larutan asam pikrat jenuh selama 10-15 menit. Dicuci dengan air mengalir 5-10 menit Dimasukkan kembali sediaan kedalam larutan eosin $2 \%$ Dilakukan dehidrasi dengan cara mencelup sediaan 2-5 menit berturutturut dalam larutan alkohol $50 \%, 70 \%, 80 \%, 95 \%$ dan dalam larutan 
alkohol absolute I dan larutan absolute II. Dijernihkan sediaan apusan dengan mencelup sediaan selama 3-5 menit berturut-turut dalam larutqnxylol I dan xylol II. Diteteskan sediaan pulasan dengan entelan dan tutup dengan kaca tutup. Sediaan diperiksa dengan mikroskop (pakai pembesaran lemah lensa obyektif10x) dan kondensor diturunkan atau diafragma dikecilkan (PinardiHadidjaja, 1990).

\section{Pemeriksaan Telur Cacing dengan Pewarnaan Hematoksilin \\ Rhodamin B}

Disiapkan semua alat dan bahan untuk pembuatan sediaan apusan tinja. Diaduk bahan suspensi telur cacing sampai homogen. Diambil dengan pipet 2-3 tetes larutan suspensi, apuskan pada kaca benda di bagian tengah sampai hampir menutupi seluruh permukaan kaca benda dikeringkan sediaan selama beberapa jam. Sediaan apusdifiksasi dengan larutan alkohol $70 \%$ selama paling sedikit 15 menit. Dicelupkan sediaan 2-5 menit berturut-turut dalam larutan alkohol $70 \%$, larutan alkohol 60\%, larutan alkohol 50\%. Dicuci dengan air mengalir 2-3 menit. Dimasukan sediaan kedalam larutan ferik-amonium sulfat $2 \%$ selama 5-15 menit. Dicuci dengan air mengalir 35 menit. Dimasukkan sediaan kedalam larutan hematoksilin 5-15 menit. Dicuci dengan air mengalir 2-3 menit. Diferensiasi dilakukan dengan mencelup sediian dalam larutan asam pikrat jenuh selama 10-15 menit. Dicuci dengan air mengalir 5-10 menit. Dimasukkan kembali sediaan kedalam larutan rhodamin $\mathrm{B}$ dengan variasi konsentrasi $1 \%, 1.5 \%, 2 \%$ dan $2.5 \%$. Dilakukan dehidrasi dengan cara mencelup sediaan 2-5 menit berturut-turut dalam larutan alkohol 50\%,70\%,80\%,95\% dan dalam larutan alkohol absolute I dan larutan absolute II. Dijernihkan sediaan apusan dengan mencelup sediaan selama 3-5 menit berturut-turut dalam larutqnxylol I dan xylol II. Diteteskan sediaan pulasan dengan entelan dan tutup dengan kaca tutup. Sediaan diperiksa dengan mikroskop (pakai pembesaran lemah lensa obyektif10x) dan kondensor diturunkan atau diafragma dikecilkan (PinardiHadidjaja, 1990).

\section{Pengamatan}

Pengamatan dilakukan oleh beberapa orang panulis yang sudah berpengalaman dalam melihat sediaan mikroskopis. Setiap panulis mendapatkan 15 buah preparat dengan kode tertentu yang hanya diketahui oleh peneliti. Data hasil pengamatan disajikan sesuai dengan parameter yang disediakan oleh panelis.

\section{Analisis Data}

Tabel 3.3 Parameter Pengukuran Preparat

\begin{tabular}{|c|}
\hline $\begin{array}{c}\text { Parameter yang Diukur dari } \\
\text { Preparat }\end{array}$ \\
\hline Kejernihan Bagian Larva \\
\hline Kelengkapan Morfologi Larva \\
\hline
\end{tabular}

Tabel 3.4 Penilaian Preparat

\begin{tabular}{|c|c|}
\hline Penilaian Preparat & Skor \\
\hline Jernih dan Lengkap & 9 \\
\hline Jernih dan Cukup Lengkap & 8 \\
\hline Jernih dan Tidak Lengkap & 7 \\
\hline Cukup Jernih dan Lengkap & 6 \\
\hline $\begin{array}{c}\text { Cukup Jernih dan Cukup } \\
\text { Lengkap }\end{array}$ & 5 \\
\hline $\begin{array}{c}\text { Cukup Jernih dan Tidak } \\
\text { Lengkap }\end{array}$ & 4 \\
\hline Tidak Jernah dan Lengkap & 3 \\
\hline $\begin{array}{c}\text { Tidak Jernih dan Cukup } \\
\text { Lengkap }\end{array}$ & 2 \\
\hline $\begin{array}{c}\text { Tidak Jernih dan Tidak } \\
\text { Lengkap }\end{array}$ & 1 \\
\hline
\end{tabular}

\section{HASIL PENELITIAN}

Berdasarkan hasil penelitian, proses penggunaan pewarna alternatif preparat permanen telur Nematoda kolon menggunakan pewarna Rhodamin $B$ 
Received: 05 September 2019 :: Accepted: 14 September 2019 :: Published: 31 Oktober 2019

yang menggunakan perlakuan variasi konsentrasi $1 \%, 1,5 \%, 2 \%$ dan $2,5 \%$ dengan kontrol dapat dilihat pada tabel 4.8 (Hasil Skor Penilaian Panelis).

Kriteria Penilaian.

Tabel 4.1 Hasil Pemeriksaan yang menggunakkan pewarna

Hematoksilin-Eosin sebagai kontrol

\begin{tabular}{|c|c|c|c|c|c|c|c|c|c|}
\hline \multirow{2}{*}{ Parameter } & \multicolumn{3}{|c|}{ Panelis 1} & \multicolumn{3}{|c|}{ Panelis 2} & \multicolumn{3}{|c|}{ Panelis 3} \\
\hline & C1 & C2 & C3 & C1 & C2 & C3 & C1 & C2 & C3 \\
\hline $\begin{array}{l}\text { Kejelasan } \\
\text { lapang } \\
\text { pandang }\end{array}$ & \multirow{3}{*}{5} & \multirow{3}{*}{8} & \multirow{3}{*}{9} & \multirow{3}{*}{9} & \multirow{3}{*}{9} & \multirow{3}{*}{9} & \multirow{3}{*}{5} & \multirow{3}{*}{9} & \multirow{3}{*}{9} \\
\hline $\begin{array}{l}\text { Kelengkapan } \\
\text { bagian telur }\end{array}$ & & & & & & & & & \\
\hline $\begin{array}{l}\text { Kontras } \\
\text { warna telur }\end{array}$ & & & & & & & & & \\
\hline Rata-rata & \multicolumn{3}{|c|}{7} & \multicolumn{3}{|c|}{9} & \multicolumn{3}{|c|}{8} \\
\hline $\begin{array}{l}\text { Kesimpulan } \\
\text { hasil }\end{array}$ & \multicolumn{3}{|c|}{$\begin{array}{l}\text { Jelas, } \\
\text { Lengkap } \\
\text { Dan Cukup } \\
\text { Sempurna }\end{array}$} & \multicolumn{3}{|c|}{$\begin{array}{l}\text { Jelas, } \\
\text { Lengkap } \\
\text { dan } \\
\text { Sempurna }\end{array}$} & \multicolumn{3}{|c|}{$\begin{array}{l}\text { Jelas, Cukup } \\
\text { Lengkap } \\
\text { Dan } \\
\text { Sempurna }\end{array}$} \\
\hline
\end{tabular}

Keterangan :

C1 = Kontrol preparat 1 (Hematoksilin Eosin)

C2 $=$ Kontrol preparat 2 (Hematoksilin Eosin)

C3 $=$ Kontrol preparat 3 (Hematoksilin Eosin)

Tabel 4.2 Hasil Pemeriksaan yang menggunakkanpewarna

Hematoksilin - Rhodamin B 1\%

\begin{tabular}{|c|c|c|c|c|c|c|c|c|c|}
\hline \multirow{3}{*}{$\begin{array}{c}\text { Paramet } \\
\text { er }\end{array}$} & \multirow{2}{*}{\multicolumn{3}{|c|}{ Panelis 1}} & \multirow{2}{*}{\multicolumn{3}{|c|}{ Panelis 2}} & \multirow{2}{*}{\multicolumn{3}{|c|}{ Panelis 3}} \\
\hline & & & & & & & & & \\
\hline & V1 & $\mathbf{V} 2$ & $\begin{array}{l}\mathbf{V} \\
\mathbf{3}\end{array}$ & $\begin{array}{l}\mathbf{V} \\
\mathbf{1}\end{array}$ & $\begin{array}{l}\mathbf{V} \\
\mathbf{2}\end{array}$ & $\begin{array}{l}\mathbf{V} \\
\mathbf{3}\end{array}$ & V1 & $\begin{array}{l}\mathbf{V} \\
\mathbf{2}\end{array}$ & $\begin{array}{l}\mathbf{v} \\
\mathbf{3}\end{array}$ \\
\hline $\begin{array}{c}\text { Kejelasan } \\
\text { lapang } \\
\text { pandang }\end{array}$ & \multirow{3}{*}{5} & \multirow{3}{*}{3} & \multirow{3}{*}{9} & \multirow{3}{*}{9} & \multirow{3}{*}{9} & \multirow{3}{*}{9} & \multirow{3}{*}{8} & \multirow{3}{*}{7} & \multirow{3}{*}{5} \\
\hline $\begin{array}{c}\text { Kelengka } \\
\text { pan } \\
\text { bagian } \\
\text { telur }\end{array}$ & & & & & & & & & \\
\hline $\begin{array}{c}\text { Kontras } \\
\text { warna } \\
\text { telur }\end{array}$ & & & & & & & & & \\
\hline $\begin{array}{c}\text { Rata- } \\
\text { rata }\end{array}$ & \multicolumn{3}{|c|}{6} & \multicolumn{3}{|c|}{9} & \multicolumn{3}{|c|}{7} \\
\hline $\begin{array}{l}\text { Kesimpu } \\
\text { lan hasil }\end{array}$ & \multicolumn{3}{|c|}{$\begin{array}{c}\text { Jelas, Cukup } \\
\text { Lengkap Dan } \\
\text { Cukup } \\
\text { Sempurna }\end{array}$} & \multicolumn{3}{|c|}{$\begin{array}{c}\text { Jelas, } \\
\text { Lengkap } \\
\text { dan } \\
\text { Sempurna }\end{array}$} & \multicolumn{3}{|c|}{$\begin{array}{c}\text { Jelas, } \\
\text { Lengkap } \\
\text { Dan Cukup } \\
\text { Sempurna }\end{array}$} \\
\hline
\end{tabular}

Keterangan :

V1 = Perlakuan Preparat 1

(Hematoksilin - RhodaminB 1\%)

V2 = Perlakuan Preparat 2

(Hematoksilin - Rhodamin B 1\%)
V3 = Perlakuan Preparat

(Hematoksilin - Rhodamin B 1\%)

Tabel 4.3 Hasil Pemeriksaan yang menggunakkan pewarna

Hematoksilin - Rhodamin B 1.5\%

\begin{tabular}{|c|c|c|c|c|c|c|c|c|c|}
\hline \multirow{2}{*}{ Parameter } & \multicolumn{3}{|c|}{ Panelis 1} & \multicolumn{3}{|c|}{ Panelis 2} & \multicolumn{3}{|c|}{ Panelis 3} \\
\hline & X1 & $\times 2$ & X3 & $\mathbf{X 1}$ & $\times 2$ & X3 & $\mathbf{X 1}$ & $\times 2$ & $\times 3$ \\
\hline $\begin{array}{l}\text { Kejelasan } \\
\text { lapang } \\
\text { pandang }\end{array}$ & \multirow{3}{*}{9} & \multirow{3}{*}{2} & \multirow{3}{*}{6} & \multirow{3}{*}{9} & \multirow{3}{*}{9} & \multirow{3}{*}{9} & \multirow{3}{*}{9} & \multirow{3}{*}{4} & \multirow{3}{*}{6} \\
\hline $\begin{array}{l}\text { Kelengkapan } \\
\text { bagian telur }\end{array}$ & & & & & & & & & \\
\hline $\begin{array}{l}\text { Kontras } \\
\text { warna telur }\end{array}$ & & & & & & & & & \\
\hline Rata-rata & \multicolumn{3}{|c|}{6} & \multicolumn{3}{|c|}{9} & \multicolumn{3}{|c|}{6} \\
\hline $\begin{array}{l}\text { Kesimpulan } \\
\text { hasil }\end{array}$ & \multicolumn{3}{|c|}{$\begin{array}{c}\text { Jelas, Cukup } \\
\text { Lengkap } \\
\text { Dan Cukup } \\
\text { Sempurna }\end{array}$} & \multicolumn{3}{|c|}{$\begin{array}{c}\text { Jelas, } \\
\text { Lengkap } \\
\text { dan } \\
\text { Sempurna }\end{array}$} & \multicolumn{3}{|c|}{$\begin{array}{c}\text { Jelas, } \\
\text { Cukup } \\
\text { Lengkap } \\
\text { Dan Cukup } \\
\text { Sempurna }\end{array}$} \\
\hline
\end{tabular}

Keterangan :

$\mathrm{X} 1=$ Perlakuan Preparat 1

(Hematoksilin - Rhodamin B 1.5\%)

$\mathrm{X} 2=$ Perlakuan Preparat 2

(Hematoksilin - Rhodamin B 1.5\%)

$\mathrm{X} 3=$ Perlakuan Preparat 3

(Hematoksilin - Rhodamin B 1.5\%)

Tabel 4.4 Hasil Pemeriksaan yang

menggunakkanpewarnaHematoksilin -

Rhodamin B 2\%

\begin{tabular}{|c|c|c|c|c|c|c|c|c|c|}
\hline \multirow{2}{*}{ Parameter } & \multicolumn{3}{|c|}{ Panelis 1} & \multicolumn{3}{|c|}{ Panelis 2} & \multicolumn{3}{|c|}{ Panelis 3} \\
\hline & Y1 & Y2 & Y3 & Y1 & Y2 & Y3 & Y1 & Y2 & Y3 \\
\hline $\begin{array}{c}\text { Kejelasan } \\
\text { lapang } \\
\text { pandang }\end{array}$ & \multirow{3}{*}{8} & \multirow{3}{*}{9} & \multirow{3}{*}{9} & \multirow{3}{*}{9} & \multirow{3}{*}{9} & \multirow{3}{*}{9} & \multirow{3}{*}{8} & \multirow{3}{*}{9} & \multirow{3}{*}{7} \\
\hline $\begin{array}{c}\text { Kelengkapan } \\
\text { bagian telur }\end{array}$ & & & & & & & & & \\
\hline $\begin{array}{c}\text { Kontras } \\
\text { warna telur }\end{array}$ & & & & & & & & & \\
\hline Rata-rata & \multicolumn{3}{|c|}{9} & \multicolumn{3}{|c|}{9} & \multicolumn{3}{|c|}{8} \\
\hline $\begin{array}{c}\text { Kesimpulan } \\
\text { hasil }\end{array}$ & \multicolumn{3}{|c|}{$\begin{array}{c}\text { Jelas, } \\
\text { Lengkap } \\
\text { Dan } \\
\text { Sempurna }\end{array}$} & \multicolumn{3}{|c|}{$\begin{array}{c}\text { Jelas, } \\
\text { Lengkap } \\
\text { dan } \\
\text { Sempurna }\end{array}$} & \multicolumn{3}{|c|}{$\begin{array}{c}\text { Jelas, Cukup } \\
\text { Lengkap } \\
\text { Dan Cukup } \\
\text { Sempurna }\end{array}$} \\
\hline
\end{tabular}

Keterangan :

$\mathrm{Y} 1=$ Perlakuan Preparat 1

(Hematoksilin - Rhodamin B 2\%)

Y2 = Perlakuan Preparat 2

(Hematoksilin - Rhodamin B 2\%)

Y3 3 Perlakuan Preparat 3

(Hematoksilin - Rhodamin B 2\%) 
Jurnal Farmasi, e-ISSN: 2655-0814

Vol. 2 No.1 Edisi Mei-Oktober 2019

http://ejournal.medistra.ac.id/index.php/JFM

Received: 05 September 2019 :: Accepted: 14 September 2019 :: Published: 31 Oktober 2019

Tabel 4.5 Hasil Pemeriksaan yang menggunakkan pewarna

Hemaatoksilin - Rhodamin B 2.5\%

\begin{tabular}{|c|c|c|c|c|c|c|c|c|c|}
\hline \multirow{2}{*}{ Parameter } & \multicolumn{3}{|c|}{ Panelis 1} & \multicolumn{3}{|c|}{ Panelis 2} & \multicolumn{3}{|c|}{ Panelis 3} \\
\hline & Z1 & $\mathbf{Z 2}$ & $\mathbf{Z 3}$ & Z1 & $\mathbf{Z 2}$ & $\mathbf{Z 3}$ & $\mathbf{Z 1}$ & $\mathbf{Z 2}$ & $\mathbf{Z 3}$ \\
\hline $\begin{array}{c}\text { Kejelasan } \\
\text { lapang } \\
\text { pandang }\end{array}$ & \multirow{3}{*}{8} & \multirow{3}{*}{6} & \multirow{3}{*}{8} & \multirow{3}{*}{9} & \multirow{3}{*}{9} & \multirow{3}{*}{9} & \multirow{3}{*}{9} & \multirow{3}{*}{9} & \multirow{3}{*}{9} \\
\hline $\begin{array}{l}\text { Kelengkapan } \\
\text { bagian telur }\end{array}$ & & & & & & & & & \\
\hline $\begin{array}{c}\text { Kontras } \\
\text { warna telur }\end{array}$ & & & & & & & & & \\
\hline Rata-rata & \multicolumn{3}{|c|}{7} & \multicolumn{3}{|c|}{9} & \multicolumn{3}{|c|}{9} \\
\hline $\begin{array}{l}\text { Kesimpulan } \\
\text { hasil }\end{array}$ & \multicolumn{3}{|c|}{$\begin{array}{c}\text { Jelas, } \\
\text { Lengkap } \\
\text { dan Cukup } \\
\text { Sempurna }\end{array}$} & \multicolumn{3}{|c|}{$\begin{array}{c}\text { Jelas, } \\
\text { Lengkap } \\
\text { dan } \\
\text { Sempurna }\end{array}$} & \multicolumn{3}{|c|}{$\begin{array}{c}\text { Jelas, } \\
\text { Lengkap } \\
\text { dan } \\
\text { Sempurna }\end{array}$} \\
\hline
\end{tabular}

Keterangan :

$\mathrm{Z} 1=$ Perlakuan Preparat 1

(Hematoksilin - Rhodamin B 2.5\%)

$\mathrm{Z2}=$ Perlakuan Preparat 2

(Hematoksilin - Rhodamin B 2.5\%)

$\mathrm{Z3}=$ Perlakuan Preparat 3

(Hematoksilin - Rhodamin B 2.5\%)

\section{Pengolahan Data}

Dari hasil penelitian pada tabel diatas dilakukan perhitungan secara statistik menggunakan Uji Kruskal - Wallis Test dalam SPSS.UjiKruskal Wallis Test digunakan ketika asumsi ANOVA tidak terpenuhi.Uji signifikansi menggunakan uji Kruskal - Wallis Test penelitian ini termasuk non parametrik variabel karena penelitian lebih bersifat deskriptif berupa Eksperimen Observasi.Data yang dianalisis dapat berupa data ordinal maupun data nominal ( Hendry, 2012).

\section{Pengolahan Keseluruhan}

Data

Secara

Hasil Data Statistik Deskriptif terdapat pada Lampiran 1.1, selanjutnya dilakukan pengolahan Data Frekuensi dimana frequency merupakan kemunculan data dari setiap penilaian, kemudian dari total frequency akan menghasilkan Percent sehingga menghasilkan Cumulative Percent keseluruhan yaitu $100 \%$.

Setelah Hasil Data Frekuensi maka dibuat Uji normalitas sebagaimana yang disajikan pada Lampiran 1.3, semua kelompok data dari seluruh perlakuan antara konsentrasi pewarna Rhodamin B dengan kontrol menghasilkan nilai $p$ value $(0,357)>0,05$. Uji normalitas menggunakan metodeKolmogorovSmirnov Test, sehingga tidak ada pelanggaran asumsi normalitas pada data tersebut karena kelompok data data yang akan diuji telah memenuhi syarat normalitas.

Selanjutnya dilakukan test statistik Kruskal Wallis Test terdapat pada Lampiran 1.4, untuk mengetahui keakuratan data sehingga didapatkan nilai $p$-value $(0,407)>0,05$, artinya tidak ada perbedaan yang signifikan pada konsentrasi pewarna Rhodamin B dari seluruh perlakuan.

\section{Pembahasan}

Pada penelitian ini digunakan sampel feses positif yang terinfeksi cacing Nematoda kolon yang digunakan sebagai sampel uji. Sampel uji didapat dari hasil survey di desa Cibeureum kecamatan Kertasari kabupaten Bandung. Penelitian ini bersifat eksperimen yang bertujuan untuk mengetahui ada atau tidaknya perbedaan yang signifikan antara pewarna alternatif Rhodamin $B$ dengan varian konsentrasi $1 \%, 1.5 \%$, $2 \%$, dan $2.5 \%$ dibandingkan dengan pewarna eosin $2 \%$ sebagai kontrol terhadap sampel uji.

Pewarnaan yang digunakan untuk pemeriksaan telur cacing pada metode hematoksilin-eosin yaitu eosin.Prinsip pewarnaannya adalah Hematoksilin bekerja sebagai pewarna basa, artinya zat ini mewarnai unsur basofilik jaringan. Tujuan pewarnaan adalah untuk meningkatkan kontras alami dan untuk lebih memperjelas berbagai unsur, dan gambaran mikroskopis telur cacing (Roland,2009). Sedangkan Eosin bersifat asam.Iaakan memulas komponen asidofilik jaringan seperti mitokondria, granula sekretoris dan kolagen. Tidak seperti hematoksilin, eosin mewarnai 
sitoplasma dan kolagen menjadi warna merah muda (Junquera, 2007).

Namun pada penelitian kali ini digunakan pewarna yang berbeda untuk pemeriksaan telur cacing.Perwarna alternatif yang dipakai pada penelitian ini adalah RhodaminB.Rhodamin B merupakan pewarna alternatif dikarenakan pewarna ini memiliki warna yang sama dengan eosin yaitu merah, dan Rhodamin B juga memliki sifat sangat larut dalam air yang akan menghasilkan warna merah dan berfluorensi kuat.

$$
\text { Dari hasil uji pendahuluan }
$$

Rhodamin B dengan konsentrasi 1\% sebagai pewarna alternatif pewarnaan telur nematoda kolon sediaan preparat permanen adalah untuk kejelasan lapang pandang terlihat jelas, untuk kelengkapan bagian telur cukup lengkap dan untuk kesempurnaan kekontrasan warna telur cukup sempurna. Pada konsentrasi $1.5 \%$ untuk kejelasan lapang pandang terlihat jelas, untuk kelengkapan bagian telur cukup lengkap dan untuk kesempurnaan kekontrasan warna telur cukup sempurna.Pada konsentrasi $2 \%$ untuk kejelasan lapang pandang terlihat jelas, untuk kelengkapan bagian telur lengkap dan untuk kesempurnaan kekontrasan terlihat sempurna.Pada konsentrasi $2.5 \%$ untuk kejelasan lapang pandang terlihat jelas, untuk kelengkapan bagian telur lengkap, dan untuk kesempurnaan kekontrasan cukup sempurna.

Hasil penelitian dan kesimpulan dari panelis 1 Rhodamin $B$ dengan konsentrasi $1 \%$ sebagai pewarna alternatif pewarnaan telur Nematoda kolon sediaan preparat permanen adalah untuk kejelasan lapang pandang terlihat jelas, untuk kelengkapan bagian telur cukup lengkap dan untuk kesempurnaan kekontrasan warna telur cukup sempurna. Pada konsentrasi $1.5 \%$ untuk kejelasan lapang pandang terlihat jelas, untuk kelengkapan bagian telur cukup lengkap dan untuk kesempurnaan kekontrasan warna telur cukup sempurna.Pada konsentrasi $2 \%$ untuk kejelasan lapang pandang terlihat jelas, untuk kelengkapan bagian telur lengkap dan untuk kesempurnaan kekontrasan terlihat sempurna.Pada konsentrasi $2.5 \%$ untuk kejelasan lapang pandang terlihat jelas, untuk kelengkapan bagian telur lengkap, dan untuk kesempurnaan kekontrasan cukup sempurna.

Hasil penelitian dan kesimpulan dari panelis 2 disimpulkan bahwa telur cacing yang ditemukan pada pewarna Rhodamin B dengan konsentrasi $1 \%$ sebagai pewarna alternatif pewarnaan telur nematoda kolon sediaan preparat permanen adalah untuk kejelasan lapang pandang terlihat jelas, lengkap dan sempurna kekontrasan warna telur sempurna. Pada konsentrasi $1.5 \%$ untuk kejelasan lapang pandang terlihat jelas, untuk kelengkapan bagian telur lengkap dan untuk kesempurnaan kekontrasan warna telur sempurna.Pada konsentrasi $2 \%$ untuk kejelasan lapang pandang terlihat jelas, untuk kelengkapan bagian telur lengkap dan untuk kesempurnaan kekontrasan terlihat sempurna.Pada konsentrasi $2.5 \%$ untuk kejelasan lapang pandang terlihat jelas, untuk kelengkapan bagian telur lengkap dan untuk kesempurnaan kekontrasan terlihat sempurna.

Hasil penelitian dan kesimpulan dari panelis 3 disimpulkan bahwa telur cacing yang ditemukan pada pewarna Rhodamin B dengan konsentrasi 1\% sebagai pewarna alternatif pewarnaan telur nematoda kolon sediaan preparat permanen adalah untuk kejelasan lapang pandang terlihat jelas, untuk kelengkapan bagian telur lengkap dan untuk kesempurnaan kekontrasan warna telur cukup sempurna. Pada konsentrasi $1.5 \%$ untuk kejelasan lapang pandang terlihat jelas, untuk kelengkapan bagian telur cukup lengkap dan untuk kesempurnaan kekontrasan warna telur 
cukup sempurna. Pada konsentrasi 2\% untuk kejelasan lapang pandang terlihat jelas, untuk kelengkapan bagian telur cukup lengkap dan untuk kesempurnaan kekontrasan terlihat sempurna. Pada konsentrasi $2.5 \%$ untuk kejelasan lapang pandang terlihat jelas, untuk kelengkapan bagian telur lengkap dan untuk kesempurnaan kekontrasan terlihat sempurna.

Hasil penelitian dan kesimpulan dari panelis menunjukkan bahwa pewarna rhodamin B bisa diaplikasikan sebagai pewarna alternatif telur cacing Nematoda kolon sediaan preparat permanen dengan variasi konsentrasi $1 \%, \quad 1.5 \%$, $2 \%$ dan $2.5 \%$. Pada konsentrasi $2 \%$ pewarna Rhodamin B lebih bagus digunakan untuk pewarna alternatif telur cacing nematoda kolon sediaan preparat permanen dikarenakan untuk kejelasan lapang pandang terlihat jelas, untuk kelengkapan bagian telur

\section{Referensi}

Ariawan Putu. (2013). Trichuristrichiura. [online]. Tersedia :http://ariawanputu2.blogspot.com /2013/10/trichuris-trichiuramantap.html

Barus, B., \& Lestari, I. (2018). PENGARUH EKSTRAK UMBI BAWANG PUTIH DAN UMBI BAWANG MERAH TERHADAP LUKA BAKAR PADA KELINCI. JURNAL FARMASIMED (JFM), 1(1), 1-5. https://doi.org/10.35451/jfm.v1i1. 86

Brown Harrold W. Dasar Parasitologi Klinis: Jakarta.PT Gremedia; 1983

Craig and Faust's.Clinical Parasitology. Eighth Edition.LEA\& FEBIGER.Philadelphia.1970

Didik Sumanto. [2010]. Faktor Risiko Infeksi Cacing Tambang Pada Anak Sekolah.[online].Tersedia :http://eprints.undip.ac.id/23985/1 /DIDIK_SUMANTO.pdf lengkap, dan untuk kesempurnaan kekontrasan warna telur terlihat jelas dan sempurna.

\section{KESIMPULAN DAN SARAN \\ Kesimpulan}

Dari hasil penelitian yang dilakukan maka dapat disimpulkan bahwa tidak terdapat perbedaan yang signifikan pada konsentrasi $1 \%, 1.5 \%, 2 \%$ dan $2.5 \%$ teradap pengaruh kualitas preparat dengan kualitas preparat kontrol.

\section{Saran}

Dari hasil penelitian disarankan untuk peneliti selanjutnya :

1. Jika menggunakan sampel feses segar sebaiknya diperiksa secara segera.

2. Adapun penelitian lanjutnya sebaiknya peneliti mengganti pewarna Rhodamin $B$ dengan pewarna lain yang memiliki sifat yang sama dengan pewarna Rhodamin B.

EtiYudiar. (2012 ). Tinjauan Pustaka. [online].Tersedia:http://digilib.uni mus.ac.id/files/disk1/120/jtptunim us-gdl-etriyudiar-5988-2-babii.pdf

EvitaPradi.(2011). Pemeriksaan Telur Cacing. [online]. Tersedia:http://digilib.unimus.ac.id /files/disk1/139/jtptunimus-gdlrevidwisal-6941-3babii.pdfhttp://digilib.unila.ac.id/6 615/20/BAB\%20II.pdf (di unduh pada 27 Agustus 2015)

Fadhlan Muchlas. [2010]. Cacing tambang. [online]. Tersedia :http://crocodilusdaratensis.wordpr ess.com/2010/08/17/cacingtambang/

Gandahusada, S., HerryD.I,Wita Pribadi, 1998, Parasitologi Kedokteran, Edisi III, FKUI, Jakarta

Gandahusada, S., Herry D.I, Wita Pribadi, 2006, Parasitologi Kedokteran, Cetakan ke-VI, FKUI, Jakarta 
Gracia S. Lynne dan David A. Bruckner, 1996, Diagnostik Parasitologi Kedokteran, Buku Kedokteran EGC, Jakarta

Hadidjaja P, 1994, Penuntun Laboratorium Parasitologi Kedokteran, EGC, Jakarta

Hadidjaja P, dan Gandahusada S, 2002, Atlas Parasitologi Kedokteran, Gramedia

HardidjajaPinardi MPH \& TM. Penuntun Laboratorium Parasitologi Kedokteran. FKUI. Jakarta. Cetak ulang 1994.

Jeffry dan Leach.AtlasHelmintologi dan Parasitologi Kedokteran.Edisi 2. EGC; 1983

Jeffrey H.C, Leach, R.M, 1993, AtlasHelmintologi dan Parasitologi Kedokteran, EGC, Jakarta

Lynnes S Garcia David A Bruckner. Alih Bahasa Dr. Robby Makimian Ms. Diagnostic Parasitologi Kedokteran: EGC; 1996

NatadisastraDjaenudin, dkk.(2009). Parasitologi Kedokteran. Jakarta

Nur Fitri Handayani. [2013]. Rhodamin B. [online]. Tersedia :https://nurfitrihandayani4840110 35.wordpress.com/2013/10/23/ide ntifikasi-penggunaan-zat-pewarnarhodamin-b-pada-pembuatankerupuk/(di unduh pada 27 Agustus 2015)

Onggowaluyo Jangkung Samidjo. Parasitologi medic 1 (Helmintologi) : Pendekatan aspek Identifikasi, diagnose, dan klinis / Jangkung SamidjoOnggowaluyo. Jakarta. EGC. 2001

Parhan, P. (2018). Penetapan Kadar NaSiklamat Pada Minuman Serbuk Instan Dan Minuman Kemasan Kaleng Yang Diperdagangkan Di Delitua Dengan Metode Alkalimetri. JURNAL FARMASIMED (JFM), 1(1), 11-15. https://doi.org/10.35451/jfm.v1i1. 88

Rita Dewi Muhardini. (2012). Laporan Praktikum Parasitologi Pemeriksaan Feses. [online].Tersedia :http://ritapoltekkes.blogspot.com/ 2012/05/laporan-praktikumparasitologi.html
SeptianNasution.(2012). Ascaris/umbrico ides. [online]. Tersedia:http://septinas.blogspot.c om/2012/11/ascarislumbricoides.html

Soejoto dan Sobeari.(1996). Penuntun Praktikum Parasitologi Medik. Solo

SrisasiGandahusada, Herry D, Wita Pribadi. Parasitologi Kedokteran. Edisi ketiga: Jakarta. FKUI; 2004

Soedarto.Helmintologi Kedokteran. Cetakan 2 :Jakarta. EGC; 1995

Soejoto dan Soebari. Parasitologi Medik Jilid 3 Protozoologi dan Helmintologi: Solo. EGC; 1996

SutantoI, Is Suhariah I, Pudji K Sjarifuddin, Saleha S. Parasitolongi Kedokteran. Edisi ke 4. Balai Penerbit FKUI. Jakarta. 2008

Sutanto, Inge., 2009. Buku Ajar Parasitologi Kedokteran.FakultasKedoteran Universitas Indonesia. Jakarta.

Yamaguchi, Tomio. Alih Bahasa Lesmana Padma sutra, $\mathrm{R}$ makimian, Monika Jukiani Y. Atlas Berwarna Parasitologi Klinik.EGC; 1992.Pustaka Utama, Jakarta 